DOI: $10.14451 / 2.153 .23$

\title{
ПРОБЛЕМЫ ОПРЕДЕЛЕНИЯ КОМПЕТЕНЦИИ СУДОВ В ОТНОШЕНИИ КОРПОРАТИВНЫХ СПОРОВ
}

\author{
(C) 2021 Чуракова Е. H. \\ кандидат юридических наук \\ Самарский государственный экономический университет, Россия, Самара \\ E-mail: churakovaen@gmail.com \\ (c) 2021 Акопян Н. T. \\ магистрант \\ Самарский государственный экономический университет, Россия, Самара \\ E-mail: nane.akopyan@mail.ru \\ (c) 2021 Байских С.A. \\ магистрант \\ Самарский государственный экономический университет, Россия, Самара \\ E-mail: svetlana.dandy@gmail.com
}

\begin{abstract}
В статье исследуется компетенция судов в отношении корпоративных споров и выделяются некоторые особенности рассмотрения таких споров согласно российскому законодательству. Анализируется судебная практика по исследуемой теме. Также рассматриваются понятия «корпоративные споры» в процессуальном законодательстве и «корпоративные отношения» в гражданском законодательстве в России. Сформулированы некоторые предложения рекомендательного характера для уточнения названных понятий.
\end{abstract}

Ключевые слова: корпоративное законодательство, корпоративные споры, корпоративные отношения, арбитражный процесс, третейские суды.

Первоочередная задача состоит в рассмотрении самого понятия «корпоративных споров», которое закреплено в правовых нормах. Оно закреплено в ч. 1 ст. 225.1 Арбитражного процессуального кодекса Российской Федерации (далее по тексту-АПК РФ) [1]. Корпоративными, в соответствии с данной нормой, признаются споры, которые связаны с созданием юридического лица, управлением им или участием в юридическом лице, являющемся коммерческой организацией, а также некоммерческой организацией, объединяющей коммерческие организации либо индивидуальных предпринимателей.

Стоит заметить, что данная формулировка претерпела корректировки. В предложенном виде была закреплена она в результате внесения изменений в 2018 г. Так, ранее в данной статье содержалось перечисление отдельных разновидностей некоммерческих организаций, являющихся объединением коммерческих организаций и индивидуальных предпринимателей [12]. Такая мера была направлена на уточнение компетенции арбитражных судов в отношении корпоративных споров.
Прежде чем говорить об особенностях рассмотрения корпоративных споров арбитражными судами, необходимо разобраться в самой природе корпоративных отношений. Ведь, прежде всего предметный признак является основанием, по которому выделяются корпоративные споры среди иных.

Базовые положения, касающиеся корпоративных отношений, в нормах гражданского законодательства содержатся (абз. 6 п. 1, абз. 4 п. 2 ст. 67 Гражданского кодекса Российской Федерации (далее по тексту-ГК РФ)) [2]. Так, гражданское законодательство регулирует, согласно ст. 2 ГК РФ, в том числе, и корпоративные отношения. В этой же норме и содержится дефиниция данного понятия. Согласно этой норме, это отношения, которые связаны с участием в корпоративных организациях либо же с управлением ими. Стоит подчеркнуть и то, что корпоративные отношения регулируются как нормами гражданского законодательства, так и нормами учредительных документов самой корпорации.

Исходя из определения корпоративных отношений, данного в ГК, такие отношения суще- 
ствуют на протяжении всего периода членства участника в корпорации лишь между самой корпорацией и ее участниками. Поэтому справедливо говорить и согласиться с позицией многих юристов, которые настаивают, что корпоративный спор следует в любом случае из корпоративных отношений. Например, в рамках корпоративного спора только участники непосредственно этой корпорации могут требовать возмещения причиненных юридическому лицу убытков или же признания сделок недействительными [3].

Следовательно, не может из таких отношений вытекать корпоративный спор, которые связаны, например, с деятельностью нотариусов. Составляют исключение, в тоже время, споры по удостоверению сделок с долями в уставном капитале обществ с ограниченной ответственностью. Что прямо закреплено в пп.9 п.1 ст. 225.1 АПК. Однако, стоит отметить, что многими учеными отнесение к корпоративным спорам вышеназванных также воспринимается неоднозначно. В качестве аргумента против такого законодательного решения тот аспект приводится, что данное нотариальное действие особо не отличается от нотариальной деятельности по удостоверению иных сделок. Связывают этот аргумент с тем, что сделки, которые удостоверяются нотариусом, в любом случае регулируются одинаковыми правовыми нормами. Имеется в виду гл. IX и X Основ законодательства Российской Федерации о нотариате [11]. Можно осмелиться предположить, что необходимость в закреплении этой категории в качестве одного из разновидностей корпоративных споров заключается в возникновении правовых последствий именно для участников экономического оборота. Хотя опять же, нотариус не является таким лицом, которое занимается предпринимательской деятельностью.

В целом, в теоретическом плане одним из наиболее спорных в науке вопросов является, в первую очередь, проблема компетенции арбитражных судов по рассмотрению подобных дел. Также достаточно спорным до сих пор остается, несмотря содержащееся в законе определение, понятие «корпоративных споров».

Если еще раз подвергнуть анализу определение «корпоративные споры», содержащееся в АПК РФ, то становится понятным, что не все споры, которые имеют корпоративный характер, признаются корпоративными и относятся к компетенции арбитражного суда. Мы можем, из определения выделить отличительный признак корпоративных споров. Имеется в виду, что связаны такие споры именно «с созданием юридического лица, управлением им или участием в юридическом лице, являющемся коммерческой организацией» [10].

Достаточно долго в науке велись споры о том, какие именно корпоративные споры относятся к компетенции арбитражного суда. Обсуждалось и то, должны ли по правилам именно главы 28.1 АПК РФ они рассматриваться. Данный вопрос рассмотрел Верховный Суд РФ и внес определенность в данной проблеме. Он отметил, что к компетенции арбитражных судов относится рассмотрение споров о признании недействительными решений собраний участников и иных органов коммерческих организаций, ассоциаций (а также союзов) коммерческих организаций, а также то, что относятся споры иных некоммерческих организаций, объединяющих коммерческие организации и/или индивидуальных предпринимателей, некоммерческих организаций, являющихся саморегулируемыми организациями и объединяющими субъектов предпринимательской деятельности, а также решений собраний участников гражданско-правовых сообществ, не являющихся юридическими лицами, но которые объединяют этих юридических лиц и/или индивидуальных предпринимателей [7].

Все иные же споры, связаны которые с созданием, управлением или участием в других корпорациях, являющихся некоммерческими организациями, должны рассматриваться судами общей юрисдикции, а не арбитражными (п. 3 ст. 50, п. 1 ст. 65.1 ГК РФ, ст. 22 ГПК РФ).

Следовательно, можно заключить, что спор, связанный с участием, например, потребительского кооператива, который имеет статус некоммерческой организации, исходя из субъектного состава, а также характера спорных отношений, не является корпоративным спором, указанным в ст. 225.1 АПК РФ. И в связи с этим не подлежит такой спор рассмотрению арбитражным судом и относится к подсудности суда общей юрисдикции [6].

Данное разделение компетенции судов характеризуется тем, что арбитражные суды, в соответствии с ст. 1 АПК РФ, осуществляют правосудие, в первую очередь, в сфере предпринимательской, а также иной экономической деятельности. Поэтому и кроме характера спора 
для его квалификации в качестве корпоративного является важным и субъектный критерий. Данные аспекты, следовательно, для отнесения спора к корпоративным должны учитываться в совокупности.

Хотелось бы остановиться на некоторых примерах из судебной практики, в которых затрагиваются проблемы компетенции судов по рассмотрению корпоративных споров. В данных примерах указывалось о неправильной квалификации спора судом.

Так, Арбитражный суд Северо-Западного округа 19 января 2018 г. по делу № А5639205/2017 рассмотрел жалобу, где податель ссылался на то, что товарищества собственников жилья являются хозяйствующими субъектами. Что они также ведут экономическую деятельность. И исходя из этого, спор между такими субъектами должен быть рассмотрен именно арбитражным судом. Более того, сторона ссылалась на отнесение спора к корпоративным.

Арбитражный суд не удовлетворил эти требования, которые содержались в кассационной жалобе. Суд отметил, что споры о признании недействительными решений собраний участников иных гражданско-правовых сообществ рассматриваются судами общей юрисдикции, если иное законом не установлено. В силу ст. 50 ГК РФ ТСЖ тоже относится к категории некоммерческих организаций. Как мы знаем, эта такая категория юридических лиц, для которых извлечение прибыли в качестве основной цели деятельности не является. И как следствие, в таких организациях не распределяют полученную прибыль между ее участниками. Кроме того, не поименованы в числе организаций, споры с участием которых на основании статьи 225.1 АПК РФ отнесены к специальной компетенции арбитражных судов [4].

Например, по другому делу арбитражный суд отказал в удовлетворении требования о признании недействительными решений, которые директором общества были приняты в виде уведомления об увеличении арендной платы по договорам субаренды. Аргументируя это тем, что такие уведомления не относятся к корпоративным решениям органов управления общества, которые возможно обжаловать в порядке АПК РФ [5]. Поэтому такой спор не может быть отнесен к корпоративным.

Можно заметить, что прежде всего суды для квалификации спора как корпоративного по ст. 225.1 АПК РФ исходят из характера заявленных истцом требований. Например, по одному делу арбитражный суд отметил, что корпоративный спор, в котором предметом иска является требование о признании за истцом - физическим лицом, права собственности на объекты недвижимого имущества, не зарегистрированные в ЕГРН, находившиеся в пользовании предприятия, исключенного из единого государственного реестра юридических лиц арбитражным судом не разрешается. Такой вывод сделан в силу того, что спор с осуществлением экономической деятельности не связан. И в связи с тем, что требования истца не относятся к перечню, указанному в ст. 225.1 АПК РФ, данный спор не является корпоративным [8].

Отмечая компетенцию судов общей юрисдикции и арбитражных судов по рассмотрению такой категории споров, нельзя не упомянуть о том, что за исключением некоторых, корпоративные споры могут быть переданы на рассмотрение третейского суда. Это стало возможным в соответствии с правилами, введёнными с 1 сентября 2016 г., однако, только при соблюдении важного условия. То есть юридическое лицо, все его участники, а также и иные лица, которые выступают истцами или ответчиками в таких спорах, должны заключить третейское соглашение об их передаче в третейский суд.

Можно заключить, что каждый раз арбитражный суд пользуется критериями квалификации корпоративного спора для разрешения вопроса компетенции по его рассмотрению. Такими выделяются, в частности, следующие два: характер спорного правоотношения и субъектный состав [9].

Стоит еще подчеркнуть, что многие юристы часто отмечают несовершенство закрепленного в АПК РФ определения «корпоративные споры». В виду того, что такая формулировка понятия оставляет большой простор для отнесения всяких споров к корпоративным. И как следствие к компетенции арбитражных судов. Можно согласиться с мнением, что перечень корпоративных споров, который закреплен в АПК РФ, исчерпывающим не является. Хотя иногда суды и отмечают обратное. Кроме того, возможно даже необходимо круг лиц закрепить, которые обладают правом на обращение в суд с требованием о возбуждении дела по корпоративному спору. Сказанное связано с тем, что иногда проблемой становится участие физического лица в споре в качестве ответчика. 


\section{Библиографический список}

1. Арбитражный процессуальный кодекс Российской Федерации от 24.07.2002 № 95 - Ф3 - Текст: электронный // СПС Консультант плюс (дата обращения: 26.01.2021).

2. Гражданский кодекс Российской Федерации (часть первая) от 30.11.1994 N 51-Ф3 (ред. от 08.12.2020) // СПС Консультант плюс (дата обращения: 26.01.2021).

3. Морозова А. П. Научно-практический комментарий к Арбитражному процессуальному кодексу Российской Федерации от 24.07.2002 N 95-Ф3 (постатейный) - Текст: электронный // -URL: www.consultant.ru/cons/cgi/ online.cgi?req=doc \&base=CMB \&n=18530\#08307022490673306 (дата обращения: 18.01.2021).

4. Постановление Арбитражного суда Северо-Западного округа (ФАС СЗО) от 19 января 2018 г. по делу № А5639205/2017- Текст: электронный // - URL: https://sudact.ru/arbitral (дата обращения: 27.01.2021).

5. Постановление АС Северо-Западного округа от 05.06.2017 N Ф07-2856/2017 по делу N A05-8448/2016 Текст: электронный // - URL https://base.garant.ru/41247408/ (дата обращения: 25.01.2021).

6. Постановление Девятого арбитражного апелляционного суда (9 ААС) от 19 сентября 2019 г. по делу № A40128256/2019 - Текст: электронный // - URL: https://sudact.ru/arbitral/doc (дата обращения: 25.01.2021).

7. Постановление Пленума Верховного Суда РФ от 23.06 .2015 N 25 «О применении судами некоторых положений раздела I части первой Гражданского кодекса Российской Федерации» - Текст: электронный - URL: www.consultant.ru/document/cons_doc_LAW_181602/ef8b3fc29212d069e19db14fe2edc70b3d6bc37c/ (дата обращения: 27.05.2020).

8. Постановление Третьего арбитражного апелляционный суд (3 АAC) от 18 июня 2019 г. по делу № A337778/2019- Текст: электронный].// - URL: https://sudact.ru/arbitral/doc/ (дата обращения: 29.05.2020).

9. Решетникова И. В. [и др.] Практика применения арбитражного процессуального кодекса РФ. Москва: Издательство Юрайт, 2020. - 480 с. - (Профессиональные комментарии). - ISBN 978-5-9916-6410-3. - Текст: электронный // ЭБС Юрайт [сайт]. - URL: https://urait.ru/bcode/449885 (дата обращения: 28.05.2020).

10. Рогалева М. А. Особенности рассмотрения дел по корпоративным спорам (ГЛ. 28.1 АПК РФ) - Текст: электронный // СПС Консультант плюс (дата обращения: 28.05.2020).

11. Терентьев А. В. Корпоративные споры в современном российском законодательстве // Электронное приложение к «Российскому юридическому журналу», 2019, N 3. С. 69-74.

12. Федеральный закон от 28.11.2018 N 451-Ф3 «О внесении изменений в отдельные законодательные акты Российской Федерации» - Текст: электронный // - URL: www.consultant.ru/document/cons_doc_LAW_312093/ (дата обращения: 27.05.2020). 